\title{
THE EFFECT OF METHYL JASMONATE AND PHENOLIC ACIDS ON GROWTH OF SEEDLINGS AND ACCUMULATION OF ANTHOCYANINS IN COMMON BUCKWHEAT (Fagopyrum esculentum Moench)
}

\author{
Marcin Horbowicz ${ }^{1}$, Halina Mioduszewska ${ }^{1}$, Danuta Koczkodaj ${ }^{1}$, Marian Saniewski \\ ${ }^{1}$ University of Podlasie, Institute of Biology, Department of Plant Physiology and Genetics, Prusa 12, 08-110 Siedlce, Poland \\ ${ }^{2}$ Research Institute of Pomology and Floriculture, Pomologiczna 18, 96-100 Skierniewice, Poland \\ e-mail: mhorbowicz@ap.siedlce.pl \\ e-mail: Marian.Saniewski@insad.pl
}

Received: 17.10.2008

\begin{abstract}
The effect of methyl jasmonate (JA-Me) and phenolic acids: trans-cinnamic acid $(t-\mathrm{CA}), \mathrm{p}$-coumaric acid $(p$-CA), salicylic acid (SA) as well as naringenine (NAR) on growth of seedlings and accumulation of anthocyanins in common buckwheat (Fagopyrum esculentum Moench) were studied. JA-Me and phenolics were applied to growth medium of 4-days etiolated buckwheat seedlings before their exposition to day/night (16h/8h) conditions. The increase of primary roots and hypocotyls length were measured after 3 days of seedling growth in such conditions. At the end of experiment the total anthocyanins contents were measured as well. Methyl jasmonate (JA-Me) and trans-cinnamic acid ( $t$-CA) inhibited growth of the primary root in young buckwheat seedlings, while naringenine (NAR) had a stimulatory influence, and $p$-coumaric acid had no effect at all. None of investigated phenolics or JA-Me had an effect on the growth of buckwheat hypocotyls, except the mixture of JA-Me and $p$-coumarcic acid. JA-Me significantly decreased the anthocyanins level in buckwheat hypocototyls, but not in cotyledons. trans-Cinnamic acid, $p$-coumaric acid and naringenine had no significant influence on the anthocyanin level in hypocotyls and cotyledons of buckwheat seedlings. Simultaneous treatment of buckwheat seedlings with JA-Me and $t$-CA or $p$-CA did not change the inhibition of anthocyanins accumulation in buckwheat hypocotyls by JA-Me. In the hypocotyls of buckwheat treated with a mixture of JA-Me and NAR, or SA, a synergistic reduction of anthocyanins was observed.
\end{abstract}

Key words: common buckwheat; methyl jasmonate; trans-cinnamic acid; $p$-coumaric acid; salicylic acid; naringenine; anthocyanins; growth of seedlings

\section{INTRODUCTION}

Phenolic compounds are some of the most widespread molecules among plant secondary metabolites, and are of great significance in plant development. The synthesis and release of phenolics are induced by va- rious biotic and abiotic factors. Tissue injury, pathogen attack, herbivory, and infection by microsymbionts, such as rhizobium, can also cause synthesis and release of phenolics (Makoi and $\mathrm{Ndakidemi}, 2007$ ). Phenolic acids in soil can have an allelopathic effect on other plants, inhibiting their growth (Hartley and $\mathrm{Wh}$ i t e h e a d, 1985). There is a hypothesis that phenolic acids may play a role of modulators of hormonal activity. According to studies by $\mathrm{Ha} \mathrm{mpt}$ on and O o sterhuis (1990), the level of phenolic acids in cotton fruit was related to abscission, sensitivity to environmental stress, ethylene evolution, and abscisic acid concentration of fruits.

Phenolic acids play an inhibitory role in plant growth. Such phenolics as: ferulic, vanillic, $p$-coumaric, $p$-hydroxybenzoic, syringic and caffeic acids inhibited the growth of roots of Pisum sativum cultured in a Hoagland nutrient solution ( $\mathrm{V} \mathrm{a} \mathrm{u} \mathrm{g} \mathrm{h} \mathrm{a} \mathrm{n} \mathrm{and} \mathrm{Ord,}$ 2006). These phenolic acids also affected root morphology in terms of extension growth of the main root and the number and size of lateral roots. At concentrations that inhibited the increase in the length of the main root, the phenolic acids also inhibited cell division.

Phenolic acid treatments of cucumber seedlings inhibited transpiration, water utilization, leaf area as well as absolute and relative rates of leaf expansion (B lu m and Gerig, 2005). The cinnamic acids, ferulic and $p$-coumaric acids were two to five times more inhibitory than the benzoic acids, $p$-hydroxybenzoic acid and vanillic acid (B l u m and G e rig, 2005).

Among the natural pigments in plants, anthocyanins are the largest water-soluble group, found in fruits, flower petals, stems and leaves. Anthocyanins belong to a large family of flavonoids which are responsible for most of the red, pink, purple, and blue co- 
lors (G r z e s i u k et al. 2007). The general function of plant anthocyanins is to attract animals and insects for flower pollination and seed dispersal, but they are also believed to protect plant cells from ultraviolet (UV) radiation (Che n et al. 2006). Anthocyanin accumulation is stimulated by various environmental stresses, such as UV and blue light, high-intensity light, wounding, pathogen attack, drought, sugar and nutrient deficiency (D ong et al. 1991; Grze siuk et al. 2008; W in ke l-S hirley, 2001).

The biosynthesis of flavonoids is a part of the general shikimate pathway which is incorporated into phenylalanine and tyrosine. The next steps of biosynthesis of all flavonoids and phenolic acids are the same: phenylalanine ammonia-lyase (PAL) deaminate L-phenylalanine to produce trans-cinnamic acid, which is then hydroxylated by cinnamate 4-hydroxylase $(\mathrm{C} 4 \mathrm{H})$ into $p$-hydroxy-cinnamic acid ( $p$-coumaric acid) (Holton and Cornish, 1995). Then, 4-coumaroyl: CoA-ligase (4CL) produces from $p$-coumaric acid the $p$-coumaroyl $\mathrm{CoA}$, and the condensation of $p$-coumaroyl CoA and malonyl CoA, through the action of chalcone synthase (CHS), forms naringenine chalcone, which is converted to flavanone naringenine that is catalysed by chalcone isomerase (CHI) (W i n -

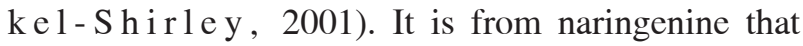
anthocyanidins and 3-deoxyanthocyanidins are derived (D i x o n and P a i v a, 1995). Along this pathway, many other products can be formed, including flavonols, flavan-3-ols, proanthocyanidins (tannins) and other polyphenolics.

Jasmonates can influence several aspects of plant growth and development, notably they induce senescence, leaf abscission and inhibit germination. The senescence response includes a loss of chlorophyll, degradation of chloroplast proteins, such as rubisco, and the accumulation of new proteins $(\mathrm{Creelman}$ and $\mathrm{Mullet}$, 1995). Methyl jasmonate (JA-Me) is one of the few plant compounds called jasmonates that is effective as a vapor at low concentrations. It has been reported that MeJA inhibits root growth in some plant species (C o r bine a u et al. 1988; S t a s wick et al. 1992).

Besides JA-Me, salicylic acid (SA) takes part in antimicrobial defense in plants but the interactions between them are complex (G l a z e b r o o k et al. 2003). SA has been shown to block jasmonate induction of several defense related genes (D o a r e s et al. 1995), and several basic pathogenesis-related genes $(\mathrm{Niki}$ et al. 1998). SA and its acetyl derivative inhibits biosynthesis of jasmonic acid in tomato leaves by blocking the conversion of 13-S-hydroxyperoxy linolenic acid to 12-oxo-phytodienoic acid ( $\mathrm{Pe} \tilde{\mathrm{n}}$ a-Cortes et al. 1993).

Low concentrations of jasmonates induce genes encoding enzymes involved in flavonoid biosynthesis (chalcone synthase and phenylalanine ammonia-lyase) (Creelman et al. 1992; Gundlach et al. 1992). Methyl jasmonate (JA-Me) vapors induced the biosynthesis of anthocyanin in light-grown soybean seedlings but inhibited anthocyanin accumulation in etiolated seedlings (Franceschi and Grimes, 1991). Exogenously applied JA-Me also induced anthocyanin accumulation in other plants (T a mari et al. 1995; S aniewski et al. 1998; S aniewski et al. 2003; $\mathrm{S}$ ani ewski et al. 2006).

Buckwheat plants accumulate various flavonoids in large concentration. Anthocyanins in the plant are accumulated in stems and leaves. In hypocotyls of common buckwheat seedlings, pink or red color appears quickly after exposition to light (H o r b o w i c z et al. 2008). Biosynthesis of light-dependent anthocyanins in buckwheat seedlings is greatly inhibited by methyl jasmonate applied at a concentration of 10-4 $\mathrm{M}(0.1 \mathrm{mM})$, as vapors or in water solution, although PAL activity was not inhibited (Horbowic z et al. 2008). The results are opposite to the stimulatory effect of JA-Me, described in scientific literature, on the formiation of anthocyanins in other plants.

Precursor feeding is one of the commonly used techniques for enhancing the secondary metabolite biosynthesis ( $\mathrm{N}$ a m d e o et al. 2007). trans-Cinnamic acid, $p$-coumaric acid and naringenine are the main intermediates of anthocyanins (ANC) biosynthesis, therefore the purpose of our studies were investigations of the influence of phenolics on ANC biosynthesis and growth of common buckwheat (Fagopyrum esculentum Moench) seedlings.

\section{MATERIALS AND METHODS}

\section{Plant material}

Seedlings of dark-grown buckwheat (Fagopyrum esculentum Moench) cv. Hruszowska were used in these studies. Seeds were germinated between two layers of wet filter paper (dimensions: $30 \mathrm{~cm} \times 10 \mathrm{~cm}$, 10 seeds placed at the upper part), which were then rolled and inserted in a 21 beaker containing ca. 200 $\mathrm{ml}$ of tap water. The germination process was carried out in darkness at $24 \pm 1^{\circ} \mathrm{C}$. After four days of dark germination the buckwheat seedlings were taken to experiments with trans-cinnamic acid, $p$-coumaric acid and naringenine (precursors of anthocyanin biosynthesis) and/or salicylic acid (SA) and methyl jasmonate (JA-Me).

In the beakers with seedlings, water was replaced with water solutions of the above mentioned intermediates, or SA alone, and with JA-Me (SigmaAldrich) at a concentration of $10^{-4} \mathrm{M}$, in the next one with $10^{-4} \mathrm{M}$ JA-Me solution, and in another one with a mixture of JA-Me and respective phenolic acid or 
naringenine. In the control samples, a new portion of water was added. To the control samples (water), the same volume of ethyl alcohol was added as that used for dissolving phenolics and JA-Me. After $8 \mathrm{~h}$ pre-incubation in darkness, the seedling samples in the beakers were exposed to 3-day light/night photoperiod. The seedlings were then grown under a $16 \mathrm{~h} / 8 \mathrm{~h}$ night/ day photoperiod and at $65 \pm 5 \%$ of relative humidity. Temperature in the growth chamber was maintained at $24 \pm 2^{\circ} \mathrm{C}$ during day and $16 \pm 2^{\circ} \mathrm{C}$ during the night period. Light intensity $\left(100 \mu \mathrm{mol} \times \mathrm{m}^{-2} \times \mathrm{s}^{-1}\right)$ was provided by fluorescent tubes. The quantities of cool white and daylight tubes used in the growth chamber were equal.

\section{Measurements}

Before and after a 3-day period of growth in such conditions, hypocotyl and root length were measured in seedlings. The differences between hypocotyl and primary root lengths before and after 3-day exposition under day/night conditions were treated as a growth increase. Mean results of lengths were obtained from $30-40$ seedlings.

At the end of the experiment anthocyanins content was determined according to the modified spectrophotometric method of Mancinelli (1984) ad- apted by Horbow ic z et al. (2008). Briefly, plant tissues were extracted with acidified $(1 \% \mathrm{HCl}, \mathrm{w} / \mathrm{v})$ methanol for $24 \mathrm{~h}$ in ambient temperature and in darkness, with occasional shaking. The extracts were carefully decanted and their absorbance was measured at $530 \mathrm{~nm}$ (peak of absorption of anthocyanin) and 657 $\mathrm{nm}$ (peak of absorption of chlorophyll degradation products). The formula $\mathrm{A}_{530}-0.25 \mathrm{~A}_{657}$ was used to compensate the absorption of chlorophyll degradation products at $530 \mathrm{~nm}$. Anthocyanin content was calculated as cyanidin-3-glucoside using 29600 as the molecular extinction coefficient and 445 as the molecular weight. Analyses were carried out for three or four independent replicates, for hypocotyls and cotyledons separately.

\section{RESULTS AND DISCUSSION}

It has been reported that MeJA inhibits root growth in some plant species (C o r b i n e a u et al. 1988). The primary root of wild-type Arabidopsis grown on agar medium was inhibited in $50 \%$ after treatment by 0.1 micromole of JA-Me (S t a s w i c k et al. 1992) On the other hand, jasmonic acid does not cause retardation of leaf emergence in broad bean ( $D$ a th e et al. 1981). The data summarized in Table 1 show that among the studied phenolic acids: trans-cinnamic acid, $p$-coumaric acid and salicylic acid, the first one inhibi-

Table 1

Effect of phenolic acids and methyl jasmonate (JA-Me) on growth of hypocotyls and primary roots in seedlings of common buckwheat. The difference between the lengths of hypocotyl and primary root before and after treatment was treated as a growth increase.

\begin{tabular}{llc}
\hline \multicolumn{1}{c}{ Treatment } & Hypocotyl & Primary root \\
\cline { 2 - 3 } & \multicolumn{2}{c}{ Increase of growth $(\mathrm{mm})$} \\
\hline Control & $32.2 \mathrm{~ns}$ & 31.7 \\
\hline Methyl jasmonate (JA-Me), $10^{-4} \mathrm{M}$ & $31.3 \mathrm{~ns}$ & $6.7 *$ \\
\hline$t$-Cinnamic acid (t-CA), $10^{-4} \mathrm{M}$ & $26.4 \mathrm{~ns}$ & $13.9 *, * *$ \\
\hline$t$-CA, $10^{-3} \mathrm{M}+\mathrm{JA}-\mathrm{Me}, 10^{-4} \mathrm{M}$ & $28.8 \mathrm{~ns}$ \\
\hline$p$-Coumaric acid (p-CA), $10^{-4} \mathrm{M}$ & $32.1 \mathrm{~ns}$ & $22.4 * *$ \\
\hline$p$-CA, $10^{-4} \mathrm{M}+\mathrm{JA}-\mathrm{Me}, 10^{-4} \mathrm{M}$ & $20.5 *$ & $2.5 * * *$ \\
\hline Naringenin (NAR), $10^{-4} \mathrm{M}$ & $30.2 \mathrm{~ns}$ & $42.1 * *$ \\
\hline $\mathrm{NAR}, 10^{-4} \mathrm{M}+\mathrm{JA}-\mathrm{Me}, 10^{-4} \mathrm{M}$ & $24.7 \mathrm{~ns}$ & $3.0 * * *$ \\
\hline Salicylic acid (SA), $10^{-4} \mathrm{M}$ & $37.6 \mathrm{~ns}$ & $30.3 * *$ \\
\hline Salicylic acid (SA), $10^{-3} \mathrm{M}$ & $33.2 \mathrm{~ns}$ & $34.6 * *$ \\
\hline SA, $10^{-4} \mathrm{M}+\mathrm{JA}-\mathrm{Me}, 10^{-4} \mathrm{M}$ & $34.7 \mathrm{~ns}$ & $6.4 *$ \\
\hline
\end{tabular}

(* - significantly different from control; ** - significantly different from methyl jasmonate treatment; ns - not significantly different). 
ted growth of the primary root only in common buckwheat seedlings. During studies of Vaughan and Ord (2006), several phenolic acids: ferulic, vanillic, $p$-coumaric, $p$-hydroxybenzoic, syringic and caffeic acids, had an inhibitory effect on roots of Pisum sativum. In our studies $p$-coumaric acid, applied at a concentration of 10-4 M, slightly inhibited growth of primary roots in common buckwheat, but the difference between control and treated samples was not significant (Tab. 1). Contrary to $t$-CA, naringenin slightly stimulated root growth. The investigated phenolics and JA-Me, applied alone or in mixture, had no influence on the growth of hypocotyls in young common buckwheat seedlings, except for the samples treated simultaneously with JA-Me and $p$-coumaric acid (Tab. 1). In this case, ca. $30 \%$ decrease of hypocotyls growth was noted.

Inhibition of root growth in seedlings of common buckwheat by JA-Me is confirmed by earlier published results of studies carried out on other plants (Corbineau et al. 1988, S ta swick et al. 1992). Simultaneous treatment of buckwheat seedlings with JA-Me and trans-cinnamic acid did not change the strong inhibitory effect of JA-Me on root growth (Tab. 1 ). In the case of simultaneous application of $p$-CA or naringenin and JA-Me, an additional decrease in primary root growth was observed (Tab. 1). Synergistic enhanced inhibition was especially clear in case of simultaneous treatment with $p$-CA and JA-Me.

Biosynthesis of anthocyanins is enhanced by light, elicitors and various plant metabolites (Franceschi and Grimes, 1991; Tamari et al. 1995; S aniewski et al. 2003; S aniewski et al. 2006; Z hang et al. 2002). Methyl jasmonate (JA-Me) stimulates the formation and the accumulation of anthocyanins in Kalanchoe blossfeldiana, Crassula multicava and tulip plants (S a n i e w ski et al. 1998; S a ni ew ski et al. 2003; S a ni e w ski et al. 2006). In contrary to the accumulation of anthocyanins in hypocotyls of common buckwheat (Fagopyrum esculentum) seedlings was strongly inhibited by JA-Me (Horbowic z et al. 2008).

The biosynthetic pathway of phenolic compounds in plants is closely related to that of anthocyanins (Konczak et al. 2005). Methyl jasmonate and $p$ coumaric acid added individually to medium induced significant changes in the composition of anthocyanin pigments and enhanced its accumulation in a sweet potato cell suspension culture (Plat a et al. 2003). Based on literature information, we expected a clear influence of phenolics on anthocyanins biosynthesis in buckwheat seedlings. trans-Cinnamic acid ( $t$-CA) added at a concentration of $10^{-4} \mathrm{M}$ did not change the level of anthocyanins in cotyledons and hypocotyls of buckwheat seedlings (Fig. 1A). Methyl jasmonate (JA-
$\mathrm{Me})$ significantly reduced the anthocyanins content in buckwheat hypocotyls, but not in cotyledons. Simultaneous treatment of buckwheat seedlings with JA-Me and $t$-CA did not change the situation: $t$-CA had no effect on the inhibition of anthocyanins synthesis in hypocotyls by JA-Me (Fig. 1A). Such results suggest that JA-Me inhibits the anthocyanins synthesis not by PAL inhibition, but in a later step or steps. In fact, JA-Me had no influence on PAL activity, which was found in our earlier studies (H o r b o w i c z et al. 2008)

Similar results to those previously described were obtained in another experiment with treatment of buckwheat seedlings with methyl jasmonate and p-coumaric acid ( $p$-CA) (Fig. 1B). Again Ja-Me $\left(10^{-4} \mathrm{M}\right)$ significantly decreased the content of anthocyanins in buckwheat hypocotyls, but not in cotyledons. Equally concentrated $p$-CA added to JA-Me solution did not change the inhibitory activity of methyl jasmonate in the synthesis of anthocyanins. $p$-CA in plants is formed by removing an amino group in L-tyrosine by tyrosine ammonia lyase (TAL), or by hydroxylation of transcinnamic acid by the action of trans-cinnamate 4-hydroxylase $(\mathrm{C} 4 \mathrm{H})$. Together with phenylalanine ammonia-lyase and 4-coumaryl CoA ligase, $\mathrm{C} 4 \mathrm{H}$ is involved in the major reactions of the phenylpropanoid metabolism (T e u t s c h et al. 1993). Similarly to PAL, TAL activity was not inhibited by JA-Me (Horbow i c z et al. 2008). Probably, JA-Me had no influence on the transformation of $t$-CA into $p$-CA, either.

Similar to trans-cinnamic acid and $p$-coumaric acid, naringenine (NAR) at a concentration of $10^{-4} \mathrm{M}$ had no significant influence on the anthocyanin level in hypocotyls and cotyledons of buckwheat seedlings (Fig. 1C). NAR added simultaneously with JA-Me caused a synergistic reduction in anthocyanin content in buckwheat hypocotyls. It probably means that JAMe do not inhibit the step of transformation of naringenine into dihydroquercetin, which can be changed into cyanidin - the major aglycone of anthocyanins occurring in buckwheat tissue (T r o y e r, 1964; K i m et al. 2007). Naringenine, another crucial intermediate in anthocyanin biosynthesis, is produced from 4-coumaryl-CoA and malonyl-CoA, first by forming chalcone (chalcone synthase enzyme), which is then converted to NAR (W i n k e l- S h i r le y, 2001). The NAR can be substrate for several further reactions: synthesis of isoflavones, flavones, flavonols, condensed tannins and/or anthocyanidins (Dix on and Paiva, 1995; Winkel-Shirley, 2001). The results obtained by us mean that feeding buckwheat seedlings with naringenine may affect the biosynthesis of several secondary metabolites, but not anthocyanins.

The jasmonate (JA) and salicylate (SA) signaling pathways in plants provide resistance to herbivorous insects and pathogens. It is known that these 

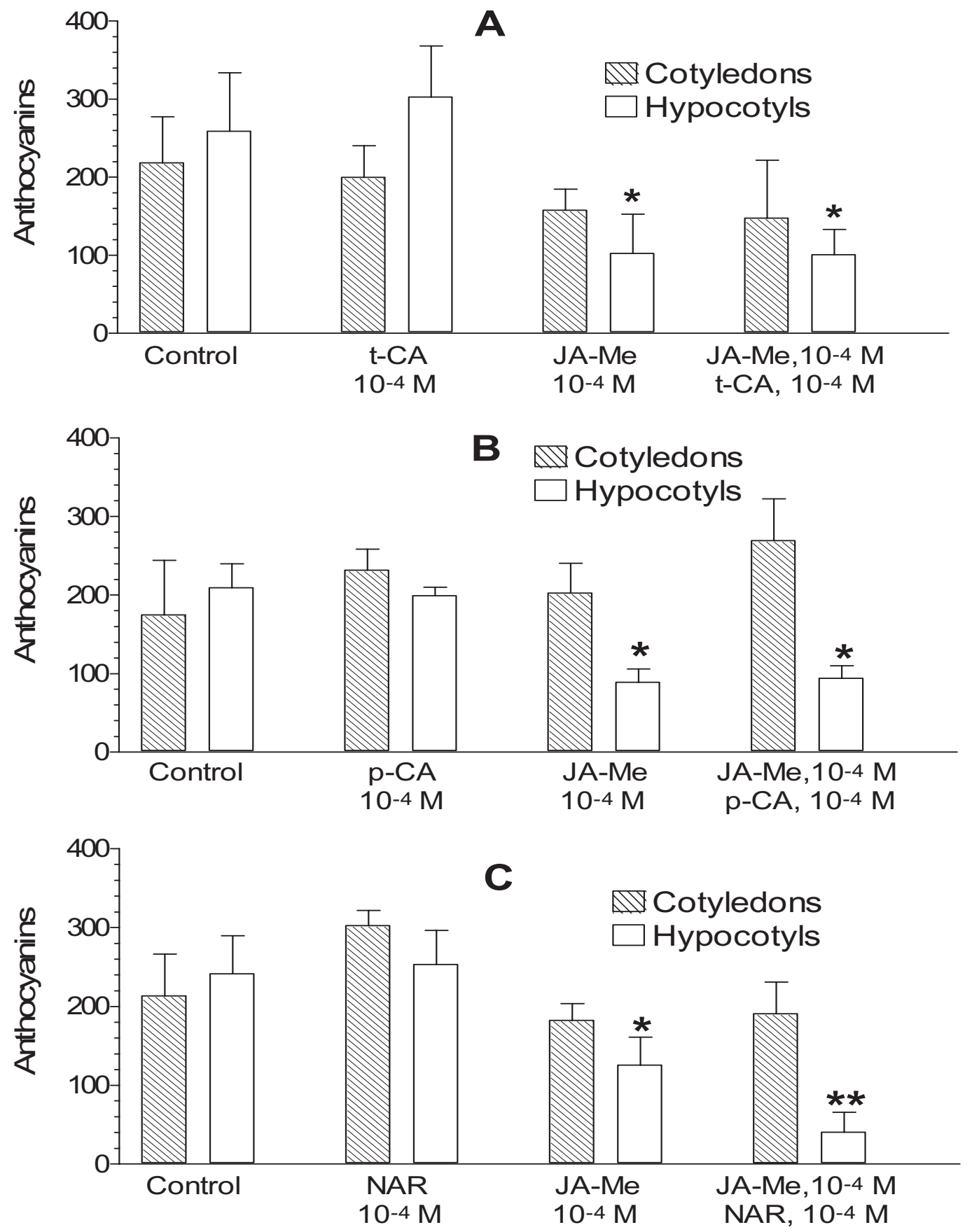

Fig. 1. Effect of trans-cinnamic acid ( $t$-CA) - graph A; $p$-coumaric acid ( $p$-CA) - graph B; naringenin - graph C, and methyl jasmonate (JA-Me) on the level of anthocyanins $\left(\mu \mathrm{g} \times \mathrm{g}^{-1}\right.$ fresh weight) in hypocotyls and cotyledons of common buckwheat seedlings. Results are mean of three replicates \pm confidence interval, $\mathrm{p}=95 \%$; bars marked with (*) means that results are significantly different from control; bars marked with $(* *)$ means that results are significantly different from control and from JA-Me treatment. 

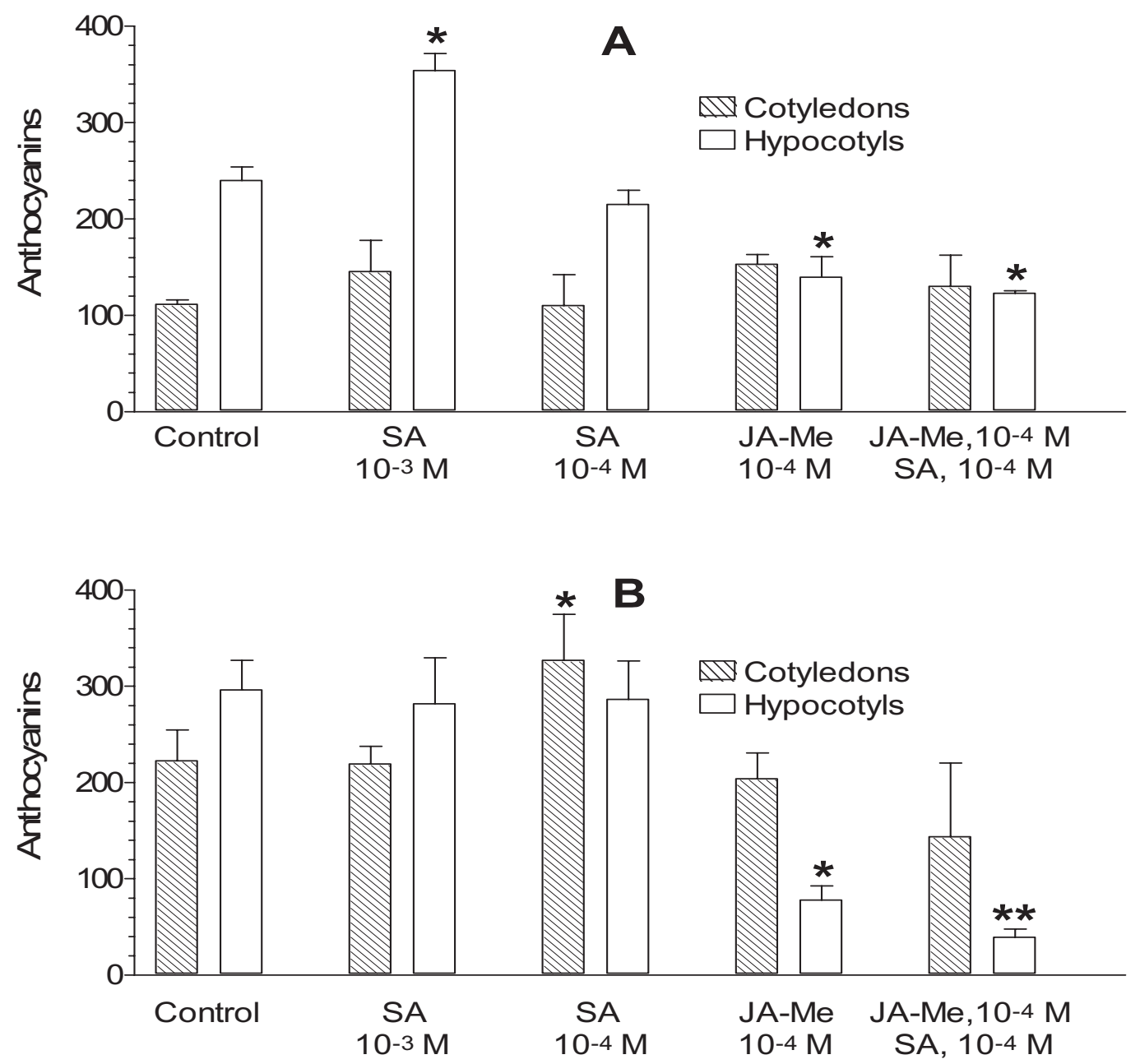

Fig. 2. Effect of salicylic acid (SA) and methyl jasmonate (JA-Me) on the level of anthocyanins $(\mu \mathrm{g} \times \mathrm{g}-1$ fresh weight) in seedlings of common buckwheat: A - whole plants; B - excised hypocotyls + cotyledons. Results are mean of three replicates \pm confidence interval, $\mathrm{p}=95 \%$; bars marked with $(*)$ means that results are significantly different from control; bars marked with $(* *)$ means that results are significantly different from control and from JA-Me treatment.

pathways interact, sometimes resulting in antagonism between the pathways ( $\mathrm{Niki}$ et al. 1998; $\mathrm{Mur}$ et al. 2006). In our studies salicylic acid at a concentration of $10^{-3} \mathrm{M}$ had a stimulatory effect on the synthesis of anthocyanins in hypocotyls of whole buckwheat seedlings (Fig. 2A). In the experiment where the roots of buckwheat seedling were removed, no influence of SA on the level of anthocyanins in hypocotyls was noted, although SA had a slight stimulatory effect on that pigment in cotyledons (Fig. 4B). In both experiments JA-Me distinctly decreased the anthocyanin content in hypocotyls, although the decline was more clear during treatment of excised seedlings (without roots). Salicylic acid applied together with JA-Me caused an additional, synergistic reduction of anthocyanins in hypocotyls of buckwheat seedlings (Fig. 2B).
$\mathrm{Zh}$ a ng et al. (2004) have studied the addition of various elicitors to Vitis vinifera suspension culture. Among the elicitors examined, jasmonic acid was the only elicitor which enhanced anthocyanin production while SA and chitosan did not have any effect. The combination of JA with SA and $\beta$-glucan decreased anthocyanin production compared with JA added as a single treatment. According to their explanation, the decrease in the level of anthocyanins is possibly explained by competition for common substrates between stilbene synthase and chalcone synthase. The stilbene synthesis was then preferable. The results of our studies probably confirm the hypothesis on competition between biosynthesis of anthocyanins and other phenylpropanoids (H o r b o w i c z et al. 2008). 


\section{CONCLUSIONS}

1. Methyl jasmonate (JA-Me) and trans-cinnamic acid $(t$-CA) inhibited growth of the primary root in young buckwheat seedlings, while naringenine (NAR) had a stimulatory influence, and $p$-coumaric acid had no effect. None of the investigated phenolics or JA-Me had an influence on the growth of buckwheat hypocotyls, except for the mixture of JA-Me and $p$-coumarcic acid.

2. JA-Me significantly decreased the level of anthocyanins in buckwheat hypocototyls, but not in cotyledons. trans-Cinnamic acid, $p$-coumaric acid and naringenine (NAR) had no significant influence on the anthocyanin level in hypocotyls and cotyledons of buckwheat seedlings.

3. Simultaneous treatment of buckwheat seedlings with JA-Me and $t$-CA or $p$-CA did not change the inhibitory activity of JA-Me on anthocyanin accumulation in buckwheat hypocotyls.

4. In hypocotyls of buckwheat seedlings treated with the mixture of JA-Me and NAR or SA a synergistic reduction in anthocyanin content was observed.

\section{Acknowlegments}

This research was supported in by grant obtained from Ministry of science and Higher Education, Poland (grant: N 310040 31/2125)

\section{REFERENCES}

B 1 u m U., G e ri g T. M., 2005. Relationships between phenolic acid concentrations, transpiration, water utilization, leaf area expansion, and uptake of phenolic acids: nutrient culture studies. J. Chem. Ecology, 31: 1907-1932.

Chen D. Q., Li Z. Y., P a n R. C., Wang X. J., 2006. Anthocyanin accumulation mediated by blue light and cytokinin in Arabidopsis seedlings. J. Integr. Plant Biol. 48: 420-425.

Corbineau F., Rudnicki, R. M., Come D., 1988. The effects of methyl jasmonate on sunflower (Helianthus annuus L.) seed germination and seedling development. Plant Growth. Regul. 7: 157-169.

Creelman R. A., Mullet J. E., 1995. Jasmonic acid distribution and action in plants: Regulation during development and response to biotic and abiotic stress. Proc. Natl. Acad. Sci. USA 92: 4114-4119.

Creelman R. A., Tierey M. L., Mullet J. E., 1992. Jasmonic acid/methyl jasmonate accumulate in wounded soybean hypocotyls and modulate wound gene expression. Proc. Natl. Acad. Sci. USA 89: 4938-4941.

Curtin C., Zhang W., Franco C., 2003. Manipulating anthocyanin composition in Vitis vinifera suspension cultures by elicitation with jasmonic acid and light irradiation. Biotechnol Lett. 25: 1131-1135.
Dathe W., Rönsch H., Pre is s A., Schade W., Sembdner G., Schreiber K., 1981. Endogenous plant hormones of the broad bean, Vicia faba L. (2) - Jasmonic acid, a plant growth inhibitor in pericarp. Planta, 153: 530-535.

Dix on R. A., Paiva N. L., 1995. Stress-induced phenylpropanoid metabolism. Plant Cell, 7: 1085-1097.

Doares S. H., Narvaez-Vasquez J., Conconi A., Ry a n C. A., 1995. Salicylic-acid inhibits synthesis of proteinase-inhibitors in tomato leaves induced by systemin and jasmonic acid. Plant Physiol. 108: 1741-1746.

Dong X., Mindrinos M., Davis K. R., 1991. Induction of Arabidopsis defense genes by virulent and avirulent Pseudomonas syringe strains and by a cloned avirulence gene. Plant Cell, 3: 61-72.

Franceschi V. R., Grimes H. D., 1991. Induction of soybean vegetative storage proteins and anthocyanins by low-level atmospheric methyl jasmonate. Proc. Natl. Acad. Sci. USA 88: 6745-6749.

Gundlach H., Miiller M. J., Kutchan T. M., Zenk M. H., 1992. Jasmonic acid is a signal transducer in elicitor-induced plant cell cultures. Proc. Natl. Acad. Sci. USA, 89: 2389-2393.

Glazebrook J., Chen W. J., Estes B., Chang H. S., Nawrath C., Metraux J. P., Zhu T., Katagiri F., 2003. Topology of the network integrating salicylate and jasmonate signal transduction derived from global expression phenotyping. Plant J. 34: 217-228.

Grzesiuk A., Dębski H., Horbowicz M., 2008. Influence of chosen factors on accumulation of anthocyanins in plants. (in Polish) Postępy Nauk Roln. 1: 81-91.

Grzesiuk A., Dębski H., Horbowicz M., Saniewski M., 2007. Occurrence, biosynthesis and accumulation of anthocyanins in plants. (in Polish) Postępy Nauk Roln. 5: 65-77.

Hampton R. E., Oosterhuis D. M., 1990. Application of phenolic acids to manipulate boll distribution in cotton. Arkansas Farm Res. 39:11-13.

Hartley R. D., Whitehead D. C., 1985. Phenolic acids in soils and their influence on plant growth and soil microbial processes. Develop. Plant Soil Sci. 16: 109-149.

Holt on T. A., Corn ish E. C., 1995. Genetics and biochemistry of anthocyanin biosynthesis. Plant Cell, 7: 1071-1083.

Horbowicz M., Grzesiuk A., Dębski H., Koczkod aj D., S a niewski M., 2008. Methyl jasmonate inhibits anthocyanins synthesis in seedlings of common buckwheat (Fagopyrum esculentum Moench). Acta Biol. Crac.. Series Bot. 50: 71-78.

Kim S. J., Maeda T., Marker M. Z., Takigawa S., Matsuura-Endo C., Yamauchi H., Mukasa Y., S a it o K., Hash i moto N., Noda T., S a ito T., Suzuki T., 2007. Identification of anthocyanins in the sprouts of buckwheat. J. Agric. Food Chem. 55: 63146318.

Konczak I., Terahara N., Yoshimoto M., Nakatani M., Yoshinaga M., Yamakawa O., 2005. Regulating the quality of anthocyanins and phenolic acids in a sweetpotato cell culture towards production of polyp- 
henolic complex with enhanced physiological activity. Trends Food Sci. Technol. 16: 377-388.

Makoi J. H. J. R, Ndakidemi P. A., 2007. Biological, ecological and agronomic significance of plant phenolic compounds in rhizosphere of the symbiotic legumes. Afric. J. Biotech. 6: 1358-1368.

Mancinelli A. L., 1984. Photoregulation of anthocyanin synthesis. VIII. Effects of light pretreatments. Plant Physiol. 75: 447-453.

Mur L. A. J., Kenton P., Atzorn R., Miersch O., Waste r n a ck C., 2006. The outcomes of concentration-specific interactions between salicylate and jasmonate signaling include synergy, antagonism, and oxidative stress leasing to cell death. Plant Physiol. 140: 249-262.

Namdeo A. G., Jadhav T. S., R a i P. K., Gavali S., Mahadik K. R., 2007. Precursor feeding for enhanced production of secondary metabolites: a review. Pharmacognosy Reviews, 1: 227-231.

Niki T., Mitsuhara I., Seo S., Ohtsubo N., Ohashi Y., 1998. Antagonistic effect of salicylic acid and jasmonic acid on the expression of pathogenesis-related (PR) protein genes in wounded mature tobacco leaves. Plant Cell Physiol. 39: 500-507.

Peńa-Cortes H., Albrecht T., Prat S., Weiler E. W., Will mitzer I., 1993. Aspirin prevents wound-induced gene expression in tomato leaves by blocking jasmonic acid biosynthesis. Planta, 191: 123-128.

Plata N., Konczak-Islam I., Jaram S., McClelland K., Woolford T., Franks P., 2003. Effect of methyl jasmonate and p-coumaric acid on anthocyanin composition in a sweet potato cell suspension culture. Biochem. Engin. J, 14: 171-177.

Saniewski M., Miszczak A., Kawa-Miszczak L., Wegrzynowicz-Lesiak E., Miyamoto K., Ue d a J., 1998. Effects of methyl jasmonate on anthocyanin accumulation, ethylene production, and $\mathrm{CO}_{2}$ evolution in uncooled and cooled tulip bulbs. J. Plant Growth Regul. 17: 33-37.

Saniewski A., Horbowicz M., Puchalski J., 2006. Induction of anthocyanins accumulation by methyl jasmonate in shoots of Crassula multicava Lam. Acta Agrobot. 59: 43-50.

Saniewski M., Horbowicz M., Puchalski J., Ueda J., 2003. Methyl jasmonate stimulates the formation and the accumulation of anthocyanin in Kalanchoe blossfeldiana. Acta Physiol. Plant. 25: 143-149.

Staswick P. E., Su W., Howell S. H., 1992. Methyl jasmonate inhibition of root growth and induction of a leaf protein are decreased in an Arabidopsis thaliana mutant. Proc. Natl. Acad. Sci. USA, 89: 6837-6840.

Tamari G., Borochov A., Atzorn R., We is s D., 1995. Methyl jasmonate induces pigmentation and flavonoid gene expression in petunia corollas: in possible role in wound response. Physiol. Plant. 94: 45-50.

Teutsch H. G., Hasenfratz M. P., Le sot A., Stolts C., Garnier I.-M., Jelt s ch J.-M., D urst F., WerckReichhart D., 1993. Isolation and sequence of a cDNA encoding the Jerusalem artichoke cinnamate 4-hydroxylase, a major plant cytochrome P450 involved in the general phenylpropanoid pathway Proc. Natl. Acad. Sci. USA, 90: 4102-4106.

Troyer J., 1964. Anthocyanin formation in excised segments of buckwheat-seedling hypocotyls. Plant Physiol. 39: 907-912.

Vaugh an D., Ord B., 2006. Influence of phenolic acids on morphological changes in roots of Pisum sativum. J. Sci. Food Agric. 52: 289-299.

Winkel-Shirley B., 2001. Flavonoid biosynthesis: a colorful model for genetics, biochemistry, cell biology, and biotechnology. Plant Physiol. 126: 485-493.

Zhang W., Curtin C., Kikuchi M., Franco C., 2002. Integration of jasmonic acid and light irradiation for enhancement of anthocyanin biosynthesis in Vitis vinifera suspension cultures. Plant Sci. 162: 459-468.

Zhang W., Voung V. T., Franco C., 2004. Regulation of anthocyanin and stilbene biosynthesis in Vitis vinife$r a$ L. suspension culture by elicitation. Proceedings of Third International Workshop on Anthocyanins ,Anthocyanins - more than nature's colours...". 27-29 January 2004, Sydney, Australia, 53.

\section{Wpływ jasmonianu metylu i kwasów fenolowych na wzrost siewek i akumulację antocyjanów w gryce zwyczajnej (Fagopyrum esculentum Moench)}

\section{Streszczenie}

Badano wpływ jasmonianu metylu (JA-Me) i kwasów fenolowych: trans-cynamonowego ( $t$-CA), $p$-kumarowego ( $p$-CA), salicylowego (SA) oraz naryngeniny (NAR) na wzrost siewek i akumulację antocyjanów w gryce zwyczajnej (Fagopyrum esculentum Moench). JA-Me i związki fenolowe zastosowano na 4-dniowe siewki wyrosłe $\mathrm{w}$ ciemności przed ich wystawieniem na warunki dnia/nocy (16h/8h). Badano także przyrost długości korzeni głównych oraz hypokotyli po 3-dniowym okresie wegetacji w takich warunkach. Wówczas też oznaczono sumaryczne zawartości antocyjanów. JA-Me i $t$-CA hamowały, podczas gdy NAR stymulowała wzrost korzeni głównych, zaś p-CA nie miał wpływu na ich wzrost. Badane związki fenolowe i JA-Me nie wpływały na wzrost hipokotyli siewek gryki zwyczajnej, za wyjątkiem jednocześnie zastosowanych JA-Me i kwasu $p$-kumarowego, które działały hamująco. JA-Me istotnie obniżał poziom antocyjanów w hipokotylach gryki, ale nie wpływał na ich zawartość w liścieniach. Kwas trans-cynamonowy, $p$-kumarowy i naryngenina nie miały wpływu na zawartość antocyjanów w hypokotylach i liścieniach siewek gryki. Jednoczesne zastosowanie JA-Me i $t$-CA lub $p$-CA nie wpłynęło na akumulację, podczas gdy użycie JA-Me wraz NAR lub SA spowodowało synergistyczne obniżenie zawartości antocyjanów w hipokotylach siewek gryki zwyczajnej. 